\title{
EFFECT OF PERCEIVED BENEFIT ON PAP SMEAR EXAMINATION UPTAKE IN WOMEN OF REPRODUCTIVE AGE: A META-ANALYSIS
}

\author{
Maranata1), Eti Poncorini Pamungkasari'), Rita Benya Adriani²) \\ ${ }^{1)}$ Masters Program in Public Health, Universitas Sebelas Maret \\ 2)Study Program of Nursing, Health Polytechnics Ministry of Heath Surakarta
}

\begin{abstract}
Background: Cervical cancer is the second most common type of cancer in women. Pap smear examination can detect early and prevent late diagnosis of cervical cancer. Perception of benefits is one of the constructs of the Health Belief Model that can predict women's intention in having a Pap smear. This study aimed to examine the effect of perceived benefit on Pap smear uptake using a meta-analysis.

Subjects and Method: A meta analysis was conducted by searching articles from PubMed, Springer Link, Google Scholar databases. Keywords used "Health Belief Model" OR "HBM" OR "Perceived Benefit" AND "Pap smear" OR "Pap Test". The inclusion criteria were full text, articles published from 2014 to 2019, and using cross sectional study design. The articles were selected by PRISMA flow chart. The quantitative data were analyzed by RevMan 5.3 .

Results: There were 6 articles that met the criteria. This study reported that strong perceived benefit increased Pap smear uptake in women of reproductive age $(\mathrm{aOR}=1.15 ; 95 \% \mathrm{CI}=1.06$ to 1.24; $\mathrm{p}<0.001$ ) with $\mathrm{I}_{2}=88 \%$.

Conclusion: Strong perceived benefit increases Pap smear uptake in women of reproductive age.
\end{abstract}

Keywords: perceived benefit, pap smear, cervical cancer, health belief model

\section{Correspondence:}

Maranata. Masters Program in Public Health, Universitas Sebelas Maret. Jl. Ir. Sutami 36A, Surakarta 57126, Central Java. Email: maranataima@gmail.com. Mobile: o85867548771.

The $7^{\text {th }}$ International Conference on Public Health

Solo, Indonesia, November 18-19, 2020 | 313

https://doi.org/10.26911/the7thicph.03.133 